\title{
A NEW DEFERMENT PROCEDURE FOR MATHEMATICIANS
}

In April, 1943, a deferment procedure for mathematicians, involving the National Committee on Physicists and Mathematicians, was authorized under Activity and Occupation Bulletin No. 35. This was explained fully in a memorandum distributed to chairmen of departments of mathematics on May 11, 1943, and reproduced in the July issue of this Bulletin and in the June-July issue of the American Mathematical Monthly. By this procedure employers were advised to send the original copy of form $42 \mathrm{~A}$ to the National Committee for evaluation. From the Committee, the form was returned to the local board with an appropriate statement by the Committee concerning the advisability of the deferment. The National Committee was also empowered to appeal cases of registrants for whom occupational deferment was not granted by the local board. Under this arrangement, the Committee has performed its duties well and effectively.

Activity and Occupation Bulletin No. 35, which authorizes the activities of the National Committee, is to be rescinded in the near future, over the strong protests of representatives of mathematics and physics. The Committee will therefore cease to exist and will no longer be available to advise local boards on problems connected with the deferment of mathematicians. The new procedure for persons engaged in the occupations defined as critical in Local Board Memorandum No. 115, revised August 16, 1943, is described in Local Board Memorandum 115B which is reproduced at the end of this memorandum. Only those cases in which occupational deferment is refused by the local board will become involved in this procedure.

In the August 16 revision of Local Board Memorandum 115, a list of critical occupations, which includes mathematicians, was set up.

The following represents a summary of the occupational deferment procedure for the critical occupations:

1. The employer continues, as in the past, to present his case for deferment to the local board through the use of Form 42A.

2. The local board will arrive at a classification for the registrant on the basis of the evidence submitted to it by the employer. It may, if it so desires, consult with the local United States Employment Service Office concerning classification. (LBM 115 and LBM 115-C)

3 . The local board will then make its decision. If occupational deferment is granted, no further action is involved during the period covered by the deferment. If, however, deferment is refused, and the registrant is placed in I-A, the case is continued as follows. 
4. If no appeal is taken within the 10-day period allowed for this purpose, the local board is directed to refer the case to the local (local with respect to the registrant's local board) office of the United States Employment Service and a 30-day stay of induction is granted to permit action by this office.

5. If an appeal is taken and the local board's decision is reversed, the registrant will be reclassified, and the case is closed for the duration of the deferment period. If, however, the I-A classification made by the local board is supported by the appeal board, the case must be referred to the local U.S.E.S. office.

6. When the local U.S.E.S. office receives a case from the local board either directly (4, above), or after appeal (5, above), it may certify to the local board either that

a. the registrant should be deferred in his present position, or

b. that they have succeeded in placing the registrant in a new position.

In the first case the local board is directed to reopen the classification of the registrant, and presumably will grant occupational deferment. In the second case, a further period of 10 days is given the registrant for the filing of a new Form $42 \mathrm{~A}$ requesting occupational deferment in his new position, and on the basis of which the local board shall reopen the classification.

7. If the U.S.E.S. fails to present any notification to the local board during the period allowed, or if it certifies that the registrant is needed in new employment, but does not succeed in placing the man in such employment, the local board may proceed with the induction of the registrant.

8. The local offices of the U.S.E.S. can refer cases reaching them and involving persons in "critical" professional and scientific occupations to the National Roster of Scientific and Specialized Personnel. The details of the relation between the U.S.E.S. offices and the Roster have not been fully defined.

The following suggestions are made to facilitate the proper functioning of the procedure herein outlined.

(1) It becomes of even greater importance than heretofore that an employer's original presentation of a case to the local board for occupational deferment or continuation of deferment be made as strong as possible. No opportunity for strengthening a case should be overlooked.

(2) The employer having once requested occupational deferment should be prepared to appeal every case in which such deferment is refused by the local board. This again implies that the original presen- 
tation should be as strong as possible, so as to stand up under an appeal.

(3) If an appeal does not secure deferment, the employer should take it upon himself to see that the case is referred to the local U.S.E.S. office, as directed by Local Board Memorandum 115-B. It is possible that the local board may not be familiar with the requirement that they do this.

(4) The employer should take steps to insure that a case which has reached the U.S.E.S. office is actually referred by it to the National Roster.

(5) It should be noted that there is no clear statement as to whether an appeal may be taken after the action of the U.S.E.S. Presumably an appeal could be taken at this time, but it is implied in LBM 115-B that the proper time for an appeal is immediately (within 10 days) after the local board's original I-A classification.

(6) In case the procedures here listed have been followed and misclassification of important personnel nevertheless results, the $\mathrm{Na}$ tional Roster should be informed regarding the particulars of the case.

The Secretary of the Society will be interested in learning of the experiences of department chairmen with the new procedure. Such information will give our representatives in Washington and the War Policy Committee a basis for judging the effectiveness of the plan.

October 20, 1943

J. R. KLINE, Secretary 
National Headquarters

\title{
SELECTIVE SERVICE SYSTEM
}

Washington, D. C.

\section{LOCAL BOARD MEMORANDUM NO. 115-B}

\author{
IsSUED: $9 / 1 / 43$
}

\section{SUBJECT: REGISTRANTS IN CRITICAL OCCUPATIONS}

1. Importance of critical occupations. - Attached to Local Board Memorandum No. 115, amended August 16, 1943, is a List of Critical Occupations. Only 149 occupations are included on the list, and it is estimated that there are not more than 400,000 registrants of military age throughout the country who have the skills required of the critical occupations. This number is exceedingly small in comparison to the total working force in industry. It can be safely said that the critical occupations as listed by the War Manpower Commission represent the highest levels of skills within industry and that, therefore, all production necessary to the war effort is directly dependent upon the most efficient use within industry of persons qualified in these occupations.

2. Need for extending every consideration for occupational deferment to registrants in critical occupations. - It is of the utmost importance that registrants (1) who have the necessary qualifications, (2) who are utilizing them to the fullest extent in a critical occupation in war production or in support of the war effort, and (3) whose removal from their present employment would have an adverse effect upon the maintenance of required production schedules, be given the most serious consideration for extended occupational deferment before being reclassified out of a deferred classification into a class available for service.

3. Referral to United States Employment Service.-(a) Local boards are directed that whenever, after the most careful consideration, they conclude a registrant who is alleged to be in a critical occupation in war production or in support of the war effort is not entitled to occupational deferment on the basis of his present employment, to refer the registrant's name and present occupation, together with a statement of his skills and qualifications and place of present employment, to the local office of the United States Employment Service in the area in which the local board is located.

(b) This reference is mandatory and will be accomplished-

(1) If no appeal is taken, upon the expiration of the period afforded the registrant to take an appeal following classification of the registrant in Class I-A, or

(2) If an appeal is taken, upon the return of the file to the local board with the decision that the registrant is continued in Class I-A on appeal.

(c) In all such cases, local boards will delay the issuance of an Order to Report for Induction to such registrant for 30 days from the date of referral to the United States Employment Service.

(d) If, during such 30-day period, the United States Employment Service certifies to the local board that-

(1) The registrant possesses and is fully employing the qualifications required of a critical occupation in war production or in support of the war effort and his removal from his present employment would adversely affect the maintenance of his employer's required production, or 
(2) The United States Employment Service has succeeded in placing the registrant in a critical occupation in war production or in support of the war effort with another employer who requires the registrant's skills and qualifications and will fully utilize such skills and qualifications,

the local board will delay the issuance of an Order to Report for Induction to such registrant for a further period of 10 days from the receipt of such certification so as to permit the filing of a new Form $42 \mathrm{~A}$ requesting the occupational deferment of the registrant.

(e) In the event that either a Form $42 \mathrm{~A}$ is filed by a new employer with whom the registrant has been placed or certification is received from the United States Employment Service stating that the registrant is necessary in his present employment, the local board will reopen the classification of the registrant and will consider the new evidence as a basis for further occupational deferment.

(f) If, however, no notification is received from the United States Employment Service prior to the expiration of the original 30-day period following referral or, in the event certification is made, that the registrant is needed in new employment but a Form 42A is not received before the expiration of the 10-day period allowed for the filing of a new claim for deferment, the local board may proceed with the induction of the registrant.

4. Cooperation by United States Employment Service.-The War Manpower Commission is informing the United States Employment Service of the need for expediting investigation of the cases of any registrants qualified for critical occupations which are referred to it by local boards. Even though a registrant is not employed in the area in which his local board is located, reference by the local board will, nevertheless, be to the local United States Employment Service office in the local board area, and any further reference of the case to the United States Employment Service office in the area in which the registrant is employed will be undertaken and accomplished by the United States Employment Service.

5. Registrants between ages of 18 and 25 in critical occupations.-Men who are utilizing their full skills in critical occupations when the necessity for their continued retention is clearly demonstrated by their employer should be considered as registrants who are utilizing the highest skills or professional qualifications, which is the exception to the general policy expressed in Local Board Memorandum No. 158-A, requiring the release of registrants between the ages of 18 and 25 during the first 6 months of a replacement schedule. In the lower age brackets, however, employers should be required to supply complete evidence that the registrant's qualifications and skills are exceptional, are being fully utilized, and cannot be replaced.

Lewis B. Hershey, Director 